\title{
Addition of androgens to cultured hamster epididymis increases zona recognition by immature spermatozoa
}

\author{
Patricia S. Cuasnicú, Fernanda González Echeverría, Alejandra Piazza and \\ J. A. Blaquier
}

Instituto de Biología y Medicina Experimental, Obligado 2490, 1428 Buenos Aires, Argentina

\begin{abstract}
Summary. The ability of spermatozoa recovered from the successive segments of the hamster epididymis to bind to the zona pellucida was studied and a major increase was found as spermatozoa passed from the proximal to the distal portions of the corpus epididymidis ( 1.95 compared with 20 spermatozoa bound/egg). Tubules from the proximal epididymis were cultured in conditions which preserved the motility of the contained spermatozoa for $48-72 \mathrm{~h}$. Addition of $2 \mu \mathrm{M}-5 \alpha-\mathrm{DHT}$ to the culture medium for $17 \mathrm{~h}$ stimulated the incorporation of ${ }^{3} \mathrm{H}$-labelled amino acids into several protein bands whose mobility in polyacrylamide gel electrophoresis was coincident with those of glycoproteins $\mathrm{EP}_{1}-\mathrm{EP}_{6}$, previously identified as androgen-dependent in the hamster epididymis in vivo. Examination of the material extracted from washed spermatozoa with $0.5 \mathrm{M}-\mathrm{NaCl}$ revealed the presence of radioactive proteins on spermatozoa. The zona-binding ability of spermatozoa from androgen-treated cultured proximal corpus tubules was significantly increased $(P<0.001)$ as was the no. of spermatozoa/egg (5.51) compared with the value for control cultures $(0.87$ spermatozoa/egg).

We suggest that androgen-dependent epididymal secretory proteins that associate with spermatozoa might participate in the formation or activation of a site for zona pellucida recognition in the sperm surface.
\end{abstract}

\section{Introduction}

The participation of androgen-dependent epididymal factors in the process of sperm maturation and the recognition that the sperm plasma membrane is the site where most maturational changes occur (see Orgebin-Crist, Danzo \& Davies, 1975; Bedford, 1975, for reviews), have stimulated research aimed at finding a role for epididymal secretory products in this process. The association of epididymal glycoproteins to spermatozoa has been described for several species (Cameo \& Blaquier, 1976; Lea, Petrusz \& French, 1978; Vierula \& Rajaniemi, 1980; Voglmayr, Fairbanks, Jackowitz \& Colella, 1980; González Echeverría, Cuasnicú \& Blaquier, 1982), but the physiological significance of this interaction remains unknown.

Since glycoproteins are known to be involved in cell-cell recognition phenomena (Hughes \& Sharon, 1978; Frazier \& Glaser, 1979), epididymal secretory glycoproteins could be associated with the assembly or activation of the site for oocyte recognition on the sperm surface.

Recent reports by Saling (1982) and Fournier-Delpech, Courtens, Pisselet, Delaleu \& Courot (1982) stress the importance of the development of the ability to bind to the zona pellucida as a determinant of the increasing fertility of spermatozoa during epididymal maturation. We have observed similar increases in the ability of human spermatozoa, obtained from successive epididymal segments, to bind to the vitelline membrane of zona-free hamster oocytes (Hinrichsen \& Blaquier, 1980). 
In the present study we have determined the profile of zona pellucida binding ability for spermatozoa from each successive segment of the hamster epididymis, and used an organ culture technique to study the effect of androgens upon glycoprotein synthesis and association with spermatozoa.

\section{Materials and Methods}

Animals. Adult male (8-12 weeks old) and immature female (5-7 weeks old) golden hamsters (Mesocricetus auratus) were maintained in $14 \mathrm{~h}$ light $/ 24 \mathrm{~h}$. Females were induced to superovulate by injection of 30 i.u. PMSG followed by 40 i.u. hCG $48-72 \mathrm{~h}$ later. The oviducts were flushed with Brinster's (1965) BMOC balanced salt solution $17 \mathrm{~h}$ after injection of hCG to recover the oocytes.

Organ culture. A technique previously used for the rat epididymis (Blaquier, 1973) was modified. Epididymides were removed under sterile conditions and separated into different segments as described by Horan \& Bedford (1972). After removing the capsule, the corpus segment was sectioned as small explants. Avoiding dissection minimized the release of spermatozoa through punctured tubules in this segment. The tissues were cultured for $1-3$ days at $33^{\circ} \mathrm{C}$ in Medium 199 with Earle's salts (GIBCO, Grand Island, NY, U.S.A.), supplemented with 100 i.u. penicillin $/ \mathrm{ml}$ and $100 \mu \mathrm{g}$ streptomycin $/ \mathrm{ml}$ and using $95 \% \mathrm{O}_{2}$ and $5 \% \mathrm{CO}_{2}$ as the gas phase. When indicated, $5 \alpha-$ dihydrotestosterone $(5 \alpha-\mathrm{DHT})(0 \cdot 1-2 \mu \mathrm{M})$ or the $3 \alpha$ - and $3 \beta$-isomers of $5 \alpha$-androstan-3,17 $\beta$-diol (2 $\mu \mathrm{M})$ were added to the medium. Cyproterone acetate (courtesy of Schering AG, Berlin, West Germany) was used at a final concentration of $4 \mu \mathrm{M}$.

Protein synthesis assay. The tubules were cultured for $27 \mathrm{~h}$ (with one medium change) in amino acid-free BMOC instead of Medium 199. Fresh medium containing $1 \mathrm{~mm}$-methionine and ${ }^{3} \mathrm{H}$ amino acid mixture (uniformly labelled, New England Nuclear, $10 \mu \mathrm{Ci} /$ plate) was added and the incubation continued for $17 \mathrm{~h}$. One half of the culture plates, selected at random, also received $5 \alpha-$ DHT during this last period.

The tubules were extensively washed, coarsely chopped with scissors and the spermatozoa released into BMOC. The tissue was then homogenized in 3 volumes of $5 \mathrm{mM}$-Tris- $38 \mathrm{mM}$-glycine buffer, $\mathrm{pH} 8 \cdot 3$, and centrifuged at $105000 \mathrm{~g}$ for $60 \mathrm{~min}$ to obtain the cytosol. Spermatozoa were washed 3 times by suspension and centrifugation in BMOC and then extracted with BMOC made $0.5 \mathrm{M}$ in $\mathrm{NaCl}$ for $30 \mathrm{~min}$ at room temperature. The extract was dialysed for $72 \mathrm{~h}$ against Trisglycine buffer and both this preparation and the cytosol were analysed by electrophoresis in $10 \%$ polyacrylamide gel slabs as previously reported (González Echeverría et al., 1982). The gels were sliced at $1 \mathrm{~mm}$ intervals, dissolved in $150 \mu \mathrm{l} 30 \% \mathrm{H}_{2} \mathrm{O}_{2}$ and counted. When required, gels were stained with Coomassie Brilliant Blue.

Zona pellucida binding test. Spermatozoa from fresh or cultured tubules were released into $0.5 \mathrm{ml}$ prewarmed $\left(37^{\circ} \mathrm{C}\right) \mathrm{BMOC}$, supplemented with $1 \mathrm{mg}$ glucose $/ \mathrm{ml}$ and $0.5 \%$ bovine serum albumin, and diluted to a concentration of $10^{6}$ cells $/ \mathrm{ml}$. Some $(20 \mu \mathrm{l})$ of this suspension was added to $20 \mu \mathrm{l}$ BMOC containing about 10 hamster oocytes, which had been incubated in BMOC for $2 \mathrm{~h}$ and in $0 \cdot 1 \%$ hyaluronidase for 5-10 min to remove cumulus cells. The gametes were incubated under a layer of mineral oil for $40 \mathrm{~min}$ at $37^{\circ} \mathrm{C}$ with a gas phase of $95 \% \mathrm{O}_{2}$ and $5 \% \mathrm{CO}_{2}$ and with shaking $(50$ oscillations $/ \mathrm{min}$ ). Oocytes were then washed 3 times by transference into fresh medium, using a finely drawn pipette as described by Hartmann \& Gwatkin (1971) to remove loosely attached spermatozoa. The number of spermatozoa firmly bound to the zona pellucida was then determined in the unfixed sample. Our experience established that 20 spermatozoa/egg was the limit at which the number of spermatozoa bound to a single oocyte could be reliably determined. To minimize error due to individual variations, paired samples (tissue from the same animal) were used in every experiment involving comparison of binding activity of spermatozoa derived from tubules cultured under different conditions. Results were analysed with the $\chi^{2}$ test (distribution of oocytes with different numbers of bound spermatozoa) or the Mann-Whitney test (mean number of spermatozoa bound per egg) for statistical significance. 
Artificial insemination. The technique described by Horan \& Bedford (1972) was used to inseminate immature females induced to superovulate.

\section{Results}

Zona pellucida binding activity of spermatozoa from different epididymal segments

The results summarized in Table 1 show that while caput spermatozoa were totally unable to recognize and bind to oocytes, this ability was present in some cells recovered from the proximal corpus epididymidis and increased abruptly when spermatozoa passed into the distal corpus and cauda. This pattern was also reflected in the mean number of spermatozoa bound per egg.

These results indicated that a major change occurred in the ability of spermatozoa to recognize oocytes during passage from the proximal to the distal portions of the corpus epididymidis. Subsequent studies therefore involved the proximal corpus epididymidis.

Table 1. Zona pellucida binding activity of spermatozoa freshly recovered from different segments of the hamster epididymis

\begin{tabular}{lcccccc}
\hline & & \multicolumn{5}{c}{ No. $(\%)$ oocytes with: } \\
\cline { 3 - 6 } $\begin{array}{c}\text { Epididymal } \\
\text { segment }\end{array}$ & $\begin{array}{c}\text { No. of } \\
\text { oocytes }\end{array}$ & $\begin{array}{c}0 \\
\text { spermatozoa }\end{array}$ & $\begin{array}{c}1-5 \\
\text { spermatozoa }\end{array}$ & $\begin{array}{c}5-10 \\
\text { spermatozoa }\end{array}$ & $\begin{array}{c}>10 \\
\text { spermatozoa }\end{array}$ & $\begin{array}{c}\text { Mean no. of } \\
\text { spermatozoa/zona }\end{array}$ \\
\hline Caput & 40 & $40(100)$ & $0(0)$ & $0(0)$ & $0(0)$ & 0 \\
Proximal corpus & 56 & $34(61)$ & $14(25)$ & $8(14)$ & $0(0)$ & $1.95 \pm 0.51$ \\
Distal corpus & 36 & $6(17)$ & $0(0)$ & $6(16)$ & $24(67)$ & $>20$ \\
Cauda & 28 & $0(0)$ & $0(0)$ & $0(0)$ & $28(100)$ & $>20$ \\
\hline
\end{tabular}

Epididymides were separated into different segments and the spermatozoa were released into prewarmed BMOC and diluted to $10^{6} \mathrm{cells} / \mathrm{ml}$. Aliquants were incubated with cumulus-free hamster oocytes for $40 \mathrm{~min}$ at $37^{\circ} \mathrm{C}$ with agitation, as described in 'Methods'. The number of spermatozoa bound to oocytes after 3 passages of the gametes through a finely drawn pipette was determined in the unfixed sample. Results are the mean of 4 experiments.

\section{Organ culture of epididymal tubules}

A set of experiments was undertaken to establish the appropriate conditions for the survival of the tissue and of spermatozoa contained in the cultured tubules. In this initial instance, the subjective estimation of the motility of spermatozoa released from the cultured tubules, compared with that of spermatozoa freshly obtained from the same segment, served as an index of viability. Spermatozoa recovered from the proximal corpus (equivalent to segment $b$ of Horan \& Bedford, 1972) exhibited undiminished motility for up to $48 \mathrm{~h}$ of culture and then a minor decrease at $72 \mathrm{~h}$.

When tubules from other segments were similarly cultured, spermatozoa from the caput and distal corpus were adversely affected by the culture procedure; motility comparable to control values was maintained for only $24 \mathrm{~h}$ and severely diminished after longer periods. Spermatozoa from the cauda tubules retained motility for $48 \mathrm{~h}$.

To characterize the system further experiments were conducted to detect whether the culture procedure affected the fertilizing ability of spermatozoa. However, since spermatozoa from the proximal corpus epididymidis are mostly infertile (Horan \& Bedford, 1972), spermatozoa obtained from control (no culture) and cultured $(24 \mathrm{~h}$ ) tubules of the cauda were used. After artificial insemination in vivo, control spermatozoa fertilized $91 / 94(96 \%)$ oocytes while spermatozoa from cultured tubules fertilized $76 / 90(84 \%)$ oocytes $(P>0.05)$. These results suggest that the culture procedure used was adequate to maintain spermatozoa contained in proximal corpus and cauda tubules for periods of $24-48 \mathrm{~h}$. 
Effect of androgens on the synthesis of epididymal glycoproteins and their association with spermatozoa

Tubules from the proximal corpus segment were cultured in BMOC containing ${ }^{3} \mathrm{H}$-labelled amino acids with and without the addition of $2 \mu \mathrm{M}-5 \alpha-\mathrm{DHT}$. The incorporation of label into macromolecules was examined by polyacrylamide gel electrophoresis of the cytosol and spermatozoa extract. Text-figure 1 shows the patterns obtained when the ratio of radioactivity incorporated in $5 \alpha$-DHT-treated cultures/control was plotted for each gel slice. Analysis of the profile indicated that the presence of androgen in the culture medium stimulated the incorporation of labelled amino acid into 6 cytosol bands (Text-fig. 1a). The electrophoretic mobilities of these peaks were coincident with those of glycoproteins $\mathrm{EP}_{1}$ to $\mathrm{EP}_{6}$, whose synthesis was stimulated by androgen administration in vivo (González Echeverría et al., 1982).

When the $0.5 \mathrm{M}-\mathrm{NaCl}$ extract of spermatozoa obtained from these cultures was examined (Textfig. 1b), several labelled proteins were again seen. The two main bands in this extract had an electrophoretic mobility coincident with those of glycoproteins $\mathrm{EP}_{2}$ and $\mathrm{EP}_{3}$ and minor radioactive peaks coincident with $\mathrm{EP}_{4}$ and $\mathrm{EP}_{5}$ were also observed.

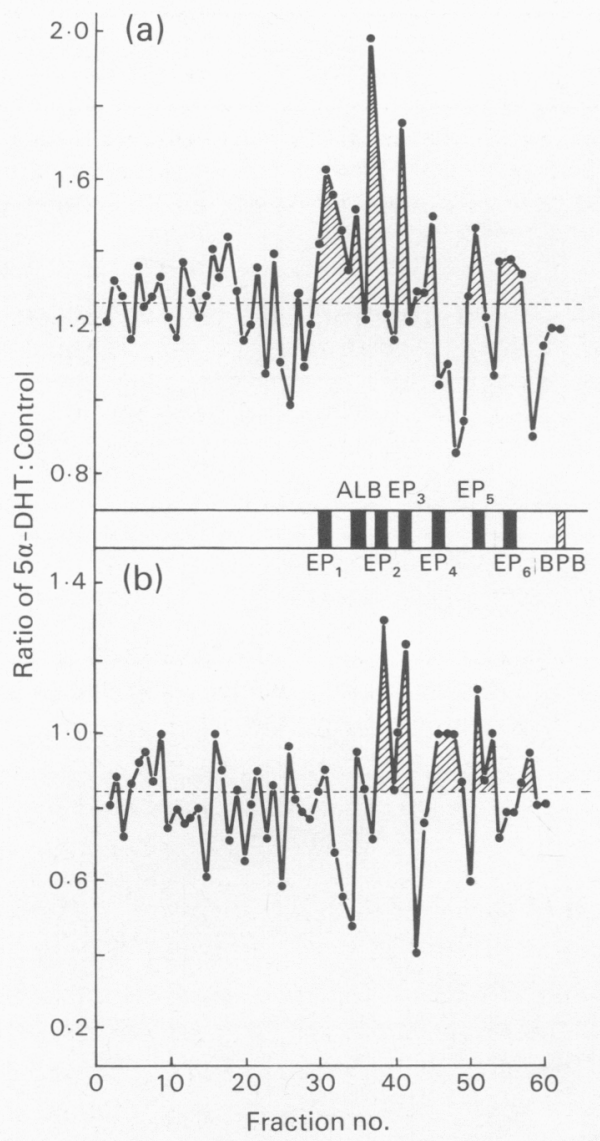

Text-fig. 1. Effect of androgen on the synthesis of hamster epididymal proteins and their interaction with spermatozoa (a) cytosol and (b) sperm extract. The broken line is the average ratio in the whole gel. The schematic representation of a gel (middle) depicts the electrophoretic mobilities of androgen-dependent glycoproteins $\mathbf{E P}_{1}-\mathrm{EP}_{6}$ (González Echeverria et al., 1982) in this system. ALB = albumin, BPB = bromophenol blue. 


\section{Effects of androgens on ability of spermatozoa to bind to the zona pellucida}

Proximal corpus tubules were cultured for $24 \mathrm{~h}$ in the presence or absence of $5 \alpha-\mathrm{DHT}$ and the ability of the spermatozoa to bind to the zona pellucida was tested. No significant changes were obtained when $5 \alpha$-DHT was present in the range $0 \cdot 1$ to $1 \mu \mathrm{M}$, but at $2 \mu \mathrm{M}$ a significant increase in zona binding ability was observed (Table 2). To test whether the effect of $5 \alpha$-DHT was specific, other androgens, such as the $3 \alpha$ - and $3 \beta$-isomers of $5 \alpha$-androstan-3,17 $\beta$-diol, were also used at $2 \mu \mathrm{M}$, but binding did not differ from control values. Proximal corpus tubules were also cultured in the presence of $2 \mu \mathrm{M}-5 \alpha$-DHT with and without the simultaneous addition of cyproterone acetate (Table 3). The antiandrogen produced a significant decrease in the zona-binding ability of spermatozoa when compared with cultures to which only $5 \alpha$-DHT was added.

Table 2. The effect of androgen added to the culture medium on the zona-binding ability of hamster spermatozoa from the proximal corpus epididymidis

\begin{tabular}{lcccccc}
\hline & \multicolumn{4}{c}{ No. (\%) oocytes with: } & \\
\cline { 3 - 6 } Treatment & $\begin{array}{c}\text { No. of } \\
\text { oocytes }\end{array}$ & $\begin{array}{c}0 \\
\text { spermatozoa }\end{array}$ & $\begin{array}{c}1-5 \\
\text { spermatozoa }\end{array}$ & $\begin{array}{c}5-10 \\
\text { spermatozoa }\end{array}$ & $\begin{array}{c}>10 \\
\text { spermatozoa }\end{array}$ & $\begin{array}{c}\text { Mean no. of } \\
\text { spermatozoa/egg }\end{array}$ \\
\hline Control & 78 & $56(72)$ & $18(23)$ & $4(5)$ & $0(0)$ & $0 \cdot 87 \pm 0 \cdot 41$ \\
$5 \alpha$-DHT & 99 & $21^{* *}(21)$ & $53^{* *}(53)$ & $11(11)$ & $15^{*}(15)$ & $5 \cdot 51 \pm 1 \cdot 85^{* *}$ \\
\hline
\end{tabular}

Paired samples (from the same animal) of proximal corpus tubules were cultured for $24 \mathrm{~h}$ in the presence or absence (control) of $2 \mu \mathrm{M}-5 \alpha$-DHT and the oocyte-binding activity of the contained spermatozoa was assessed as described in Table 1. Results are the mean of 12 independent observations. Compared with control values: ${ }^{*} P<0 \cdot 01$, ${ }^{* *} P<0 \cdot 001$.

Table 3. The effect of $5 \alpha$-DHT $(2 \mu \mathrm{M})$ and cyproterone acetate $(4 \mu \mathrm{M})$ added to the culture medium on the zona-binding ability of hamster spermatozoa from the proximal corpus epididymidis

\begin{tabular}{|c|c|c|c|c|c|c|}
\hline \multirow[b]{2}{*}{ Treatment } & \multirow[b]{2}{*}{$\begin{array}{l}\text { No. of } \\
\text { oocytes }\end{array}$} & \multicolumn{4}{|c|}{ No. $(\%)$ of oocytes with: } & \multirow[b]{2}{*}{$\begin{array}{c}\text { Mean no. of } \\
\text { spermatozoa/egg }\end{array}$} \\
\hline & & $\begin{array}{c}0 \\
\text { spermatozoa }\end{array}$ & $\begin{array}{c}1-5 \\
\text { spermatozoa }\end{array}$ & $\begin{array}{c}5-10 \\
\text { spermatozoa }\end{array}$ & $\begin{array}{c}>10 \\
\text { spermatozoa }\end{array}$ & \\
\hline $5 \alpha-\mathrm{DHT}$ & 110 & $41 \quad(37)$ & $55(50)$ & $6(6)$ & 8 (7) & $2.61 \pm 0.80$ \\
\hline $\begin{array}{l}5 \alpha-\mathrm{DHT}+\text { cyproterone } \\
\text { acetate }\end{array}$ & 111 & $69^{* *}(62)$ & $41(37)$ & $1(1)$ & $0^{*}(0)$ & $0 \cdot 79 \pm 0 \cdot 20^{* *}$ \\
\hline
\end{tabular}

Experiments were performed as described in Table 2. Results are the mean of 19 independent observations. Compared with values for $5 \alpha$-DHT treatment; ${ }^{*} P<0.02,{ }^{* *} P<0.01$.

\section{Discussion}

Fertilization involves a process of specific cell-cell recognition, adhesion and fusion mediated by complementary surface structures present in both gametes. "Bindin" has been identified as the protein responsible for the recognition and adhesion of spermatozoa to sea-urchin eggs (Vacquier \& Moy, 1977) and the complementary spermatozoa receptor on the surface of the eggs was also identified (Aketa, Tsuzuki \& Onitake, 1968; Schmell, Earles, Breaux \& Lennarz, 1977; Glabe \& Vacquier, 1978). Evidence for a sperm receptor in the mammalian zona pellucida was initially presented by Gwatkin \& Williams (1977) for hamster and mouse eggs, while Bleil \& Wassarman (1980) isolated a glycoprotein in mouse zonae pellucidae which possessed receptor activity for spermatozoa. The existence of its counterpart, the sperm plasma membrane receptor-for-zona pellucida has been postulated for the boar (Peterson, Russell, Bundman \& Freund, 1979) and the guinea-pig (Yanagimachi, Okada \& Tung, 1981). Since this receptor seems to be absent, or at least 
inactive, in immature spermatozoa, as implied by the lack of oocyte recognition and binding by spermatozoa recovered from the proximal segments of the epididymis in the mouse (Saling, 1982), ram (Fournier-Delpech et al., 1982) and hamster (this study), it seems likely that the receptor is assembled or activated during maturation.

Glycoproteins secreted by the epididymal epithelium and incorporated onto spermatozoa have been demonstrated for numerous species (Cameo \& Blaquier, 1976; Lea et al., 1978; Vierula \& Rajaniemi, 1980; Voglmayr et al., 1980) and are likely candidates for the proposed receptor in view of the key role played by these molecules in intercellular recognition and adhesion processes (Hughes \& Sharon, 1978; Frazier \& Glaser, 1979). In the hamster, such glycoproteins have been identified by Moore (1980) and González Echeverría et al. (1982) and have tentatively been shown to be involved in pre-fertilization events because specific antibodies against them significantly reduced fertility (Moore, 1981).

The experiments described in this report provide further evidence in favour of a biological role of epididymal proteins in sperm maturation. Our results show that the response of the cultured epididymal tubules and their contained spermatozoa to androgenic stimulation in vitro is qualitatively similar to that obtained by testosterone injection into castrated hamsters (González Echeverria et al., 1982), at least from the point of view of the stimulation of the synthesis of glycoproteins $\mathrm{EP}_{1}-\mathrm{EP}_{6}$ and their deposition on spermatozoa. The two main proteins associated with spermatozoa from androgen-stimulated cultures, tentatively identified as $\mathrm{EP}_{2}$ and $\mathrm{EP}_{3}$ based on their similar electrophoretic migration only, are those identified as being added to spermatozoa during epididymal transit and maturation (González Echeverría et al., 1982). However, our most relevant result is that the sperm population derived from tubules exposed to androgens developed a significantly greater ability for oocyte recognition when epididymal glycoproteins $\mathrm{EP}_{2}-\mathrm{EP}_{5}$ were added to the sperm surface.

The results of Saling (1982) for the mouse and Fournier-Delpech et al. (1982) for the ram show the apparent parallelism between the development of zona-binding activity and fertilizing ability of spermatozoa during epididymal transit. Our results for hamsters agree with this observation, since the major increase in oocyte binding ability detected as spermatozoa pass from the proximal to the distal corpus epididymidis is coincident with the increase in fertility found by Horan \& Bedford (1977). Our results support the hypothesis that androgen-dependent secretory epididymal proteins participate in the assembly or activation of a site for oocyte recognition on the sperm surface that occurs during maturation.

\section{References}

Aketa, K., Tsuzuki, H. \& Onitake, K. (1968) Characterization of the sperm-binding protein from sea urchin egg surface. Expl Cell Res. 50, 676-679.

Bedford, J.M. (1975) Maturation, transport and fate of spermatozoa in the epididymis. In Handbook of Physiology, section 7, Vol. 5, pp. 303-317. Eds D. W. Hamilton \& R. O. Greep. American Physiological Society, Washington D.C.

Blaquier, J.A. (1973) An in vitro action of androgens on protein synthesis by epididymal tubules maintained in organ culture. Biochem. Biophys. Res. Commun. 52, 1177-1183.

Bleil, J.D. \& Wassarman, P.M. (1980) Mammalian sperm-egg interaction: identification of a glycoprotein in mouse egg zonae pellucidae possessing receptor activity for sperm. Cell 20, 873-882.
Brinster, R.L. (1965) Studies on the development of mouse embryos in vitro. IV. Interaction of energy sources. J. Reprod. Fert. 10, 227-240.

Cameo, M.S. \& Blaquier, J.A. (1976) Androgen-controlled specific proteins in rat epididymis. $J$. Endocr. $69,47-55$.

Fournier-Delpech, S., Courtens, J.L., Pisselet, C.L., Delaleu, B. \& Courot, M. (1982) Acquisition of zona binding by ram spermatozoa during epididymal passage, as revealed by interaction with rat oocytes. Gamete Res. 5, 403-408.

Frazier, W. \& Glaser, L. (1979) Surface components and cell recognition. Ann. Rev. Biochem. 48, 491-523.

Glabe, C.G. \& Vacquier, V.D. (1978) Egg surface glycoprotein receptor for sea urchin sperm bindin. Proc. natn. Acad. Sci. U.S.A. 75, 881 885 . 
González Echeverría, F.M., Cuasnicú, P.S. \& Blaquier, J.A. (1982) Identification of androgen-dependent glycoproteins in the hamster epididymis and their association with spermatozoa. J. Reprod. Fert. 64, $1-7$.

Gwatkin, R.B.L. \& Williams, D.T. (1977) Receptor activity of the hamster and mouse solubilized zona pellucida before and after the zona reaction. $J$. Reprod. Fert. 49, 55-59.

Hartmann, J.F. \& Gwatkin, R.B.L. (1971) Alteration of sites on the mammalian sperm surface following capacitation. Nature, Lond. 234, 479-481.

Hinrichsen, M.J. \& Blaquier, J.A. (1980) Evidence supporting the existence of sperm maturation in the human epididymis. J. Reprod. Fert. 60, 291-294.

Horan, A.H. \& Bedford, J.M. (1972) Development of the fertilizing ability of spermatozoa in the epididymis of the Syrian hamster. J. Reprod. Fert. 30, 417-423.

Hughes, R.C. \& Sharon, N. (1978) Carbohydrates recognized. Nature, Lond. 274, 637-638.

Lea, O.A., Petrusz, P. \& French, F.S. (1978) Purification and localization of acidic epididymal glycoprotein (AEG): a sperm coating protein secreted by the rat epididymis. Int. J. Androl., Suppl. 2, 592-607.

Moore, H.D.M. (1980) Localization of specific glycoproteins secreted by the rabbit and hamster epididymis. Biol. Reprod. 22, 705-718.

Moore, H.D.M. (1981) Glycoprotein secretions of the epididymis in rabbit and hamster: localization of epididymal spermatozoa and the effect of specific antibodies on fertilization in vivo. J. exp. Zool. 215, $77-85$.

Orgebin-Crist, M.C., Danzo, B.J. \& Davies, J. (1975) Endocrine control of the development and maintenance of sperm fertilizing ability in the epididymis.
In Handbook of Physiology, section 7, Vol. 5, pp. 319 333. Eds D. W. Hamilton \& R. O. Greep. American Physiological Society, Washington D.C.

Peterson, R.N., Russell, L., Bundman, D. \& Freund, M. (1979) Sperm-egg interaction: evidence for boar sperm plasma membrane receptors for porcine zona pellucida. Science, N.Y. 207, 73-74.

Saling, P.M. (1982) Development of the ability to bind to zonae pellucidae during epididymal maturation: reversible immobilization of mouse spermatozoa by lanthanum. Biol. Reprod. 26, 429-436.

Schmell, E., Earles, B.J., Breaux, C. \& Lennarz, W.J. (1977) Identification of a sperm receptor on the surface of the eggs of the sea urchin Arbacia punctulata. J. Cell Biol. 72, 35-46.

Vacquier, V.D. \& Moy, G.W. (1977) Isolation of bindin: the protein responsible for adhesion of sperm to sea urchin eggs. Proc. natn. Acad. Sci. U.S.A. 74, 24562460.

Vierula, M. \& Rajaniemi, N. (1980) Radioiodination of surface proteins of bull spermatozoa and their characterization by dodecylsulphate-polyacrylamide gel electrophoresis. J. Reprod. Fert. 58, 483-489.

Voglmayr, J.K., Fairbanks, G., Jackowitz, M.A. \& Colella, J.R. (1980) Post-testicular developmental changes in the ram sperm cell surface and their relationship to luminal fluid proteins of the reproductive tract. Biol. Reprod. 22, 655-667.

Yanagimachi, R., Okada, A. \& Tung, K.S.K. (1981) Sperm autoantigens and fertilization. II. Effects of anti-guinea pig sperm autoantibodies on sperm ovum interactions. Biol. Reprod. 24, 512-518.

Received 11 July 1983 